\title{
EFEK PENAMBAHAN ENZIM (Amylase, Protease, Xylanase) DALAM PAKAN TERHADAP BERAT TELUR DAN DIAMETER KUNING TELUR PADA ITIK CAMPURAN
}

\author{
Ratna Widyawati ${ }^{1}$, Dian Ayu Kartika Sari ${ }^{1}$, Halimah Tusadiah ${ }^{1}$, Bagus Uda Palgunadi ${ }^{{ }^{*}}$ \\ ${ }^{1}$ Fakultas Kedokteran Hewan, Universitas Wijaya Kusuma Surabaya \\ *Email: udapalgunadi@yahoo.com
}

\begin{abstract}
The purpose of this research aims to determine the effect of adding enzymes (amylase, protease, xylanase) in feed on egg weight and egg yolk diameter in mixed ducks. The experimental animals used were 24 laying ducks. The design used was a completely randomized design (CRD) with 4 treatments and 6 replications. The four treatments were P0 (Control), P1 (6 ducks with Avizym1502®5gram / kg), P2 (6 ducks with Avizym1502® $10 \mathrm{gram} / \mathrm{kg}$ ), and P3 (6 ducks given Avizym1502). ${ }^{\circledR} 15 \mathrm{gram} / \mathrm{kg}$ ). This treatment is carried out once a day for 9 weeks. Before the treatment, the ducks were adapted for a week. After that, the initial egg weight and yolk diameter were measured at week 0 , week 6 , and week 9 . Data obtained from the results of weighing eggs found an average value of P0 (59.1667 $\pm 3.9200 \mathrm{a}) \mathrm{g}, \mathrm{P} 15 \mathrm{gram} / \mathrm{kg}(56.1667 \pm 2.9268 \mathrm{a}) \mathrm{g}, \mathrm{P} 210 \mathrm{gram} / \mathrm{kg}$ $(60.1667 \pm 4.9966 \mathrm{a}) \mathrm{g}$, and P3 $15 \mathrm{gram} / \mathrm{kg}\left(67.6667 \pm 2.7325^{\mathrm{b}}\right) \mathrm{g}$. The results of data from examining the diameter of the egg yolk found an average value of P0 $(45.03 \pm 1.2956 \mathrm{a}) \mathrm{mm}, \mathrm{P} 15 \mathrm{gram} / \mathrm{kg}$ $(44.35 \pm 0.7969 \mathrm{a}) \mathrm{mm}, \mathrm{P} 210 \mathrm{gram} / \mathrm{kg}(45.75 \pm 1.5694 \mathrm{a}) \mathrm{mm}$, and P3 $15 \mathrm{gram} / \mathrm{kg}\left(48.83 \pm 0.7394^{\mathrm{b}}\right)$ $\mathrm{mm}$. The data obtained were then analyzed using the ANOVA test which statistically showed that there was a significant difference $(\mathrm{P}<0.05)$ between egg weight and yolk diameter in mixed ducks treated with enzymes (amylase, protease, xylanase) in the feed.
\end{abstract}

Keywords: enzymes, in feed, egg weight, yolk diameter,mixed breed ducks

\section{PENDAHULUAN}

Perkembangan ekonomi saat itu telah mengubah masyarakat yang dulunya beternak ternak untuk kebutuhan keluarga menjadi suatu bentuk usaha. Salah satu bentuk peternakan yang diharapkan dapat mencapai hasil yang baik adalah itik. Itik memiliki potensi yang besar di Indonesia, terutama sebagai penghasil daging dan telur. Seiring dengan pertambahan penduduk dan meningkatnya kesadaran dan kesadaran masyarakat akan pentingnya makan makanan bergizi, permintaan akan produk hewani semakin meningkat dari tahun ke tahun. (Satrio, dkk. 2015).

Dari segi permintaan pasar, prospek itik sangat bagus. Pasalnya, seluruh bagian itik bisa dijual, salah satunya adalah telur Itik. Telur itik memiliki kandungan protein, kalori dan lemak yang lebih tinggi dibanding telur ayam (Kriswanto dan Wulansarie, 2018), sehingga telur itik lebih diminati oleh masyarakat karena memiliki kandungan yang baik untuk tubuh manusia. Peminat telur itik yang besar juga harus diimbangi dengan kualitas telurnya. Kualitas telur dapat ditentukan oleh dua faktor, yaitu kualitas kulit luar dan kandungan telur, ketebalan putih telur, warna dan posisi kuning telur, serta kuning telur dan kuning telur tanpa bercak. Telur yang dihasilkan itik dapat dipengaruhi oleh banyak faktor, termasuk penyakit, Suhu lingkungan induk, pakan, suhu penyimpanan dan waktu penyimpanan (Musadiq, dkk. 2017). Diantara semua faktor tersebut, faktor pemberian pakan sangat penting karena sangat menentukan produksi telur pada itik. Bahan pakan itik petelur antara lain jagung kuning giling, konsentrat, dedak, dedak, tepung tulang dan bungkil kelapa. Penambahan enzim 
pada pakan itik merupakan salah satu cara untuk meningkatkan bobot telur itik dan diameter kuning telur.

Enzim telah banyak digunakan dalam berbagai produk industri, antara lain industri pertanian, kimia dan farmasi (Akhdiya, 2003). Enzim memegang peranan yang sangat penting dalam proses pencernaan makanan dan metabolisme zat makanan dalam tubuh. Selain itu, fungsi enzim itu sendiri adalah untuk mereduksi energi aktivasi. Energi aktivasi adalah energi yang dibutuhkan untuk mencapai keadaan transisi (bentuk dengan tingkat energi tertinggi) dalam reaksi kimia. Reaksi yang dapat dikatalisis oleh enzim memiliki energi aktivasi yang lebih rendah dan oleh karena itu membutuhkan lebih sedikit energi untuk melakukan reaksi. Dipercaya bahwa enzim dapat mempercepat reaksi kimia tertentu tanpa pembentukan produk sampingan, dan bekerja dalam larutan pada suhu dan kondisi $\mathrm{pH}$ tertentu. Aktivitas enzim juga dapat dipengaruhi oleh banyak faktor, seperti konsentrasi enzim, konsentrasi substrat, suhu dan pH (Pelczar dan Chan, 2005).

\section{MATERI DAN METODE}

Jenis peneltian yang digunakan adalah penelitian eksperimental dengan beberapa dosis enzim enzim (Avizyme1502®) (amilase, protease,dan xylanase) yang digunakan untuk pemberian pakan pada itik campuran betina fase layer. Selanjutnya dilakukan analisa indikator berat telur dan diameter kuning telur pada itik campuran untuk mengetahui efek pemberian enzim (Avizyme1502®).

\section{A.Lokasi Dan Waktu Penelitian}

Penelitian ini dilakukan di Desa Kalikatir, kecamatan Gondang, Mojokerto Untuk pemeriksaan sampel dilakukan di Tempat pelaksanaan penelitian dengan meteran jangka sorong dan kitchen scale (timbangan dapur elektronik) Waktu penelitian ini akan dilakukan pada 18 Juni 2020 hingga 26 Agustus 2020.

\section{B.Alat dan Bahan}

Pada penelitian ini menggunakan alat sebagai berikut: kandang Itik tipe ren dengan panjang $2 \mathrm{~m}$, lebar $2 \mathrm{~m}$, tinggi depan $40 \mathrm{~cm}$, tinggi belakang $40 \mathrm{~cm}$, dan Kandang box dengan Panjang 1m, lebar $1 \mathrm{~m}$, tinggi 1 meter, yang dilengkapi tempat makan dan air minum. Kandang box Hanya digunakan apabila terdapat Itik yang butuh penanganan Khusus. Untuk satu kandang baterai diisi 6 ekor Itik sehingga dalam penelitian ini diperlukan kandang ren berjumlah 4 buah.

Penelitian ini menggunakan itik campuran 24 ekor dan Dedak Padi Super S-00 Produksi POKPHAND yang berwarna Merah dengan Komposisi sebagai berikut: jagung giling, dedak, konsentrat, dan avizym 1502® produksi $\mathrm{du}$ pont danisco dengan komposisi amilase, protease, xylanase.

\section{Prosedur Penelitian}

\section{Teknik Pengambilan Sampel}

Sampel Itik dibeli dalam keadaan sehat dan memiliki warna atau tanda yang berbeda-beda dari perternakan Itik yang ada di suatu di daerah Kabupaten Mojokerto. Ada beberapa yang di beri tanda dengan bahan henna,kunyit,dan pewarna alami lainnya. Pewarnaan ini bertujuan agar sampel tidak tertukar. Dalam melakukan pengambilan perlakuan dan urutan sampel, dilakukan suatu teknik pengambilan sampel atau elemen secara acak, Kemudian lot diambil satu persatu bersamaan dengan pengambilan sampel secara acak guna menentukan perlakuan terhadap sampel. Penelitian ini membutuhkan 24 ekor Itik dengan ratarata umur 22 minggu.

Mulai hari pertama pemberian enzim Avizym 1502® (amilase, protease, dan xylanase) sampai ke minggu 9 dilakukan penimbangan berat telur dan diameter kuning telur itik sebanyak 3 kali. Yaitu 
pada minggu ke 0 , minggu ke 6 dan minggu ke 9. Pemberian enzim amilase, protease, dan xylanase pada pakan terhadap berat telur itik dan diameter kuning telur Itik diamati dari setiap perlakuan ini mengikuti kebutuhan nutrisi pakan itik Petelur berdasarkan fasenya.

Penelitian ini menggunakan Rancangan Acak Lengkap ( RAL) dengan 4 perlakuan, tiap perlakuan 6 ulangan setiap ulangan terdiri dari 1 ekor Itik sehingga di dapatkan jumlah itik 1 x 6 x 4 $=24$ ekor.Jumlah ini diambil berdasarkan rumus Federer, yaitu :

$$
\begin{aligned}
& (\mathbf{t}-\mathbf{1})(\mathbf{n}-\mathbf{1})>\mathbf{1 5} \\
& \mathrm{t}=\text { jumlah kelompok } \\
& \mathrm{n}=\text { jumlah sampel }
\end{aligned}
$$

\section{Pemberian Pakan Itik Campuran}

Asupan pakan yang dibutuhkan itik campuran petelur pada fase layer adalah 160-180 gram perharinya. Pemberian pakan ini ditambahi dengan dosis berbedabeda setiap perlakuannya. $\mathrm{P} 0=$ Kelompok Itik yang hanya di berikan pakan dan air minum sebagai kontrol. Pemberian pakan dilakukan 3 kali sehari $/ 60 \mathrm{~g} /$ ekor. $\mathrm{P} 1=$ Kelompok Itik perlakuan pertama yang diberikan enzim (Avizym1502®) (amilase, protease,dan xylanase) sebanyak $5 \mathrm{gram} / \mathrm{kg}$ di lakukan selama selama 9 Minggu. Pemberian pakan dilakukan 3 kali sehari/60g/ekor. P2 = Kelompok Itik perlakuan kedua yang diberikan enzim Avizym1502@(amilase, protease, dan xylanase) sebanyak $10 \mathrm{gram} / \mathrm{kg}$ pakan di lakukan selama 9 Minggu. Pemberian pakan dilakukan 3 kali sehari/60g/ekor. P3 $=$ Kelompok Itik perlakuan ketiga diberikan enzim (Avizym 1502®) (amylase, protease, dan xylanase) sebanyak $15 \mathrm{gram} / \mathrm{kg}$ pakan di lakukan selama 9 Minggu. Pemberian pakan dilakukan 3 kali sehari/60g/ekor

\section{HASIL}

Hasil pemeriksaan berat telur pada Itik campuran selama 9 minggu dengan pemberian enzim amilase, protease, dan xylanase (Avizym1502®) dengan perlakuan $\mathrm{P} 0=$ Kontrol, $\mathrm{P} 1=$ Pemberian enzim amilase, protease, dan xylanase (Avizym1502®) $5 \mathrm{gr} / \mathrm{kg}, \mathrm{P} 2=$ Pemberian enzim amilase, protease, dan xylanase (Avizym1502®) $10 \mathrm{gr} / \mathrm{kg}$, dan P3 = Pemberian enzim amilase, protease, dan xylanase (Avizym1502®) $15 \mathrm{gr} / \mathrm{kg}$. disajikan dalam tabel berikut :

Tabel 1. Nilai rata-rata berat telur pada itik dengan pemberian enzim amilase, protease, dan xylanase selama 9 minggu.

\begin{tabular}{cc}
\hline Perlakuan & Rata-rata \pm SD $(\mathbf{g})$ \\
\hline P0 (Kontrol) & $59.1667 \pm 3.9200^{\mathrm{a}}$ \\
\hline $\begin{array}{c}\text { P1 (5gr Enzim amilase, } \\
\text { protease, dan xylanase) }\end{array}$ & $56.1667 \pm 2.9268^{\mathrm{a}}$ \\
\hline $\begin{array}{c}\text { P2 (10gr Enzim } \\
\text { amilase, protease, dan } \\
\text { xylanase) }\end{array}$ & $60.1667 \pm 4.9966^{\mathrm{a}}$ \\
\hline $\begin{array}{c}\text { P3 (15gr Enzim } \\
\text { amilase, protease, dan } \\
\text { xylanase) }\end{array}$ & $67.6667 \pm 2.7325^{\mathrm{b}}$ \\
\hline
\end{tabular}

Berdasarkan hasil analisis statistik menunjukkan bahwa terdapat perbedaan nyata dari perubahan berat telur pada itik yang diberi enzim amilase, protease, dan xylanase $($ Avizym1502@) $(\mathrm{P}<0,05)$.

Tabel 2 Nilai rata-rata Diameter pada itik dengan pemberian enzim amilase, protease, dan xylanase selama 9 minggu.

\begin{tabular}{cc}
\hline Perlakuan & $\begin{array}{c}\text { Rata-rata } \pm \text { SD } \\
(\mathbf{m m})\end{array}$ \\
\hline P0 (Kontrol) & $45.03 \pm 1.2956^{\mathrm{a}}$ \\
\hline $\begin{array}{c}\text { P1 (5gr Enzim amilase, } \\
\text { protease, dan xylanase) }\end{array}$ & $44.35 \pm 0.7969^{\mathrm{a}}$ \\
\hline $\begin{array}{c}\text { P2 (10gr Enzim } \\
\text { amilase, protease, dan } \\
\text { xylanase) }\end{array}$ & $45.75 \pm 1.5694^{\mathrm{a}}$ \\
\hline $\begin{array}{c}\text { P3 (15gr Enzim } \\
\text { amilase, protease, dan } \\
\text { xylanase) }\end{array}$ & $48.83 \pm 0.7394^{\mathrm{b}}$ \\
\hline
\end{tabular}


Berdasarkan hasil analisis statistik menunjukkan bahwa terdapat perbedaan nyata dari perubahan diameter kuning telur pada itik yang diberi enzim amilase, protease, dan xylanase (Avizym1502®) $(\mathrm{P}<0,05)$.

\section{PEMBAHASAN}

Menurut Ketaren dan Prasetyo pada tahun (2000), Beliau mengatakan faktor umur juga dapat mempengaruhi rata-rata berat telur. Bobot telur yang dihasilkan lebih rendah (kecil), disebabkan oleh besar-kecilnya kuning telur yang diovulasikan sehingga putih telur yang dihasilkan juga sedikit. Itik yang bertelur pada pertama kali relatif kecil, 42-48 gram. Kemudian pada umur 64-67 minggu ratarata berat telur terus meningkat menjadi 76 gram, dan selama 12 bulan penelitian ratarata berat telur adalah 69,7 gram. Bobot rata-rata telur lebih tinggi dari bobot ratarata telur itik arabio yang dilaporkan dalam (Whendart dan Madyana., 1986), (Gunawan., 1987) dan (Prasetyo dan Susanti 1997).

(Wahyuni, 2008) mengemukakan bahwa pada itik petelur modern, dalam satu siklus produksi (kurang lebih 60 minggu) akan mampu menghasilkan telur dengan berat total $21 \mathrm{~kg}$, dibandingkan dengan bobot telur standar $46 \mathrm{~kg}$ atau laju konversi pakan 2,1. Penggunaan dedak padi fermentasi sampai dengan $40 \%$ $(\mathrm{P}<0,05)$ pada ayam petelur disebabkan oleh kualitas protein pakan terutama kandungan asam amino esensial pakan $\mathrm{A}$, $\mathrm{B}$, dan $\mathrm{C}$ lebih tinggi dibandingkan dengan kandungan dedak fermentasi pada pakan. Hal ini sejalan dengan pandangan (Scott et al., 1982) yang menunjukkan bahwa kualitas protein sangat berperan penting dalam menentukan produksi telur. Rasyaf (2004) menambahkan bahwa semua bahan pangan adalah asam amino esensial (metionin, lisin, Tripsin) Diperlukan untuk produksi. Hanafi (2001) menambahkan bahwa adanya kandungan asam fitat yang berada dalam bentuk ransum kompleks dengan protein, pektin, dan polisakarida bukan pati menyebabkan penggunaan dedak padi menjadi terbatas, sehingga untuk mengatasinya digunakan enzim Phylazim, yaitu campuran dari beberapa enzim seperti amilase, phitase, dan protease.

Xylanase dapat meningkatkan akses enzim endogen dan eksogen ke protein dan pati di dalam sel endosperma (Cowieson, 2005) dengan memecah arabinoksilan yang sangat bercabang di dinding sel (Chesson, 2001). Ini juga dapat menghasilkan xylose oligosaccharides yang dapat difermentasi (Fernandez et al., 2000), yang kemudian difermentasi menjadi asam lemak yang mudah menguap di sekum. Ini akan berdampak positif pada kesehatan usus melalui produksi peptida YY dan meningkatkan pencernaan dan penyerapan usus kecil (Masey O'Neill et al., 2012; Singh et al., 2012), yang menyebabkan penurunan pengosongan lambung dan transit duodenum (Cuche et al., 2000; Park et al., 2013). Telah dikemukakan bahwa Xylanase dapat mengurangi sekresi musin dengan menstimulasi fibrosis pada dinding usus (Cowieson dan Bedford, 2009). Tetapi Hipotesis pada ayam tidak meyakinkan (Sharma et al., 1997; Fernandez et al., 2000). Baru-baru ini, Kiarie et al., (2014) melaporkan bahwa Xylanase meningkatkan kinerja pertumbuhan dan AMEn dari makanan berbasis gandum dan jagung, yang menunjukkan bahwa polisakarida selain pati yang larut dan tidak larut dihidrolisis. Hasil serupa dalam diet jagung-kedelai telah dilaporkan oleh orang lain (Cowieson, 2010; Masey O'Neill et al., 2011; 2012) yang mendukung penggunaan Xylanase dalam diet berbasis jagung.

Di sisi lain, penambahan aktivitas tunggal amilase atau protease menghasilkan efek menengah pada kinerja ayam pedaging. Rasio konversi pakan dari 2 perawatan initidak berbeda secara signifikan dari single Xylanase atau 
kontrol. Gracia dkk. (2003) melaporkan bahwa suplementasi eksogen Amylase untuk diet jagung-kedelai meningkatkan kinerja ayam pedaging pada semua usia ( 7 , 21, dan 42 hari) dan meningkatkankecernaan pati dan Energi yang dapat dimetabolisme dengan koreksi nitrogen (AMEn). Begitu pula dengan Jiang, et al., (2008) melaporkan bahwa Amylase meningkatkan berat badan secara signifikan. Sebaliknya, Kaczmarek, et al. (2014) melaporkan tidak ada pengaruh Amylase terhadap kinerja pertumbuhan ayam yang diberi pakan mengandung jagung konvensional diet (diameter ratarata geometris jagung $736 \mu \mathrm{m}$ ), tetapi meningkatkan berat badan, rasio konversi pakan, dan diet Energi yang dapat dimetabolisme dengan koreksi nitrogen (AMEn) pada mereka yang diberi makan jagung yang digiling halus (diameter ratarata geometris jagung482 $\mu \mathrm{m}$ ), mungkin karena peningkatan pencernaan pati di usus bagian atas. (Gracia dkk., 2003).

(Mahagna, et al. 1995) melaporkan bahwa sekresi Amylase dan Protease endogen oleh pankreas berkurang saat burung diberi makan makanan yang dilengkapi dengan Amylase dan Protease. Jiang, et al., (2008) menemukan hal yang sama. Pengaruh amilase pada ayam broiler kinerja mungkin tergantung pada bioefikasi enzim, jagung kualitas (batu api atau penyok), ukuran partikel, kondisi pertumbuhan, kondisi pengeringan, tingkat ketahanan pati, dan rasio amilosa terhadap amilopektin

Protease telah digunakan dalam diet broiler selama hampir 20 tahun (Bedford $e t$ al., 1997). Baru-baru ini, terdapat perbedaan dengan pendapat tersebut baru dalam konsep suplementasi protease dari makanan broiler, yang terutama didorong oleh meningkatkan biaya bahan dan masalah lingkungan. Pengaruh protease terhadap kinerja ayam broiler dan daya cerna nutrisi, bagaimanapun, tidak konsisten (Naveed et al., 1998; Ghazi et al., 2003; Rutherfurd, et al.., 2007; Boguhn dan Rodehutscord, 2010; angel, et al., dkk. 2011; Romero et al., 2013, 2014). Akan tetap, (Angel, et al.,2011) melaporkan peningkatan dalam Kenaikan Berat Badan, rasio konversi pakan, dan kecernaan asam Amino lebih besar dibandingkan dengan kontrol., (Olukosi et al. 2015) Setuju dengan hal ini dan melaporkan protease meningkatkan kecernaan dari nitrogen terutama pada dosis enzim tinggi Saat menambahkan Protease di atas kombinasi Xylanase dan Amylase.

Hasil penelitian ini sejalan dengan hasil penelitian (Renema et al. 1999) dan Kwakkel et al. (1995) Hasil penelitian menunjukkan bahwa taraf protein ransum berpengaruh nyata $(\mathrm{P}<0,05)$ terhadap bobot relatif ovarium, oviduk, jumlah folikel yang memasuki fase pendewasaan (yellow yolk) dan bobot hidup saat awal peneluran serta umur awal peneluran, tetapi tidak berpengaruh nyata terhadap folikel yang belum memasuki fase pendewasaan (white yolk). Pertumbuhan ovarium terutama terjadi karena adanya pertumbuhan folikel yang menjadi dewasa (yolk). Pada saat ini berlangsung penimbunan bahan yolk (lipoprotein) yang berasal dari protein dan lemak yang dikonsumsi, sehingga tersedianya protein dan lemak yang cukup dalam ransum akan berpengaruh terhadap proses pendewasaan folikel (Gilbert, 1971). Oleh karena itu meningkatnya taraf protein ransum mengakibatkan meningkatnya konsumsi protein sehingga terjadi peningkatan pertumbuhan ovarium dan folikel.

Pada prinsip Badan Standard Nasional (SNI 3926:2008) mengatakan bahwa makin tua umur telur makin besar kuning telur, makin kecil indeks kuning telur. Telur yang baru mempunyai indeks kuning telur antara 0,33 dan 0,52 dengan rata-rata 0,42 . Diameter kuning telur biasanya dilakukan untuk menentukan kualitas Indeks Kuning Telur (IKT). Menurut Purnamaningsih (2010) Jika diameter kuning telur lebih besar, indeks kuning telur juga lebih besar. Semakin tinggi kandungan protein dan lemak dalam 
ransum, semakin tinggi indeks kuning telurnya. Sistem budidaya itik yang berbeda juga dapat menyebabkan perbedaan kualitas telur yang dihasilkan. Pemberian makanan yang terprogram ditambah dengan vitamin dan suplemen akan sangat mempengaruhi kualitas telur yang dihasilkan (Rasyaf.,2004). Ditambahkan oleh Soeparno dkk. (2011) Pergerakan air yang konstan akan menurunkan viskositas kuning telur sehingga kuning telur menjadi rata kemudian retak, karena proses perpindahan air ini tergantung pada ketebalan putih telur dan indeks kuning telur (IKT) menurun, selanjutnya membran vitelline akan rusak dan menyebabkan kuning telur pecah.

Faktor lain yang mempengaruhi kualitas telur adalah kerja hormon. Estrogen dan progesteron merangsang sintesis protein, baik protein putih telur maupun kuning telur, sehingga meningkatkan berat total keseluruhan telur. Estrogen menstimulasi sintesis protein ovalbumin, ovotransferrin dan lisozim yang diproduksi oleh kelenjar tubular magnum. Hal ini sejalan dengan penjelasan Lucy (2000) yang mengamati bahwa kelenjar magnum tubular mengeluarkan sebagian besar protein telur ayam, yang terdiri dari ovalbumin, lisozim, ovotransferrin dan ovomucin, dan akan disimpan sebagai butiran. Sekresi kelenjar tubular ini dirangsang oleh progesteron sebagaimana dijelaskan oleh Yuwanta (2004) bahwa hormon progesteron dihasilkan dari epitel supervisial ovum. Hormon progesteron merangsang hipotalamus untuk mengaktifkan hormon pelepas faktor untuk merangsang sekresi (LH) dari hipofisis anterior. Progesteron dan androgen berfungsi mengatur perkembangan saluran telur untuk sekresi albumin dari magnum. Ditambahkan (Kartadisastra, 1994) bahwa Nutrisi dalam ransum memiliki fungsi dan peran yang berbeda-beda. Di dalam tubuh Itik, nutrisi Protein pada ransum berfungsi terutama dalam pertumbuhan, produksi dan reproduksi.

(Choct, 2006; Taylor et al., 2013) Mengatakan Suplementasi Xylanase meningkatkan rasio konversi pakan dibandingkan dengan Kontrol selama fase starter dan selama seluruh periode (1-42 hari). Tidak ada pengaruh pada karakteristik enzim yang diamati dalam penelitian ini. Demikian pula, (Zanella et al., 1999) melaporkan bahwa kombinasi Xylanase, Amylase dan Protease tidak berpengaruh terhadap bobot badan mobil, lemak perut dan bobot payudara. Tetapi, (Kafe, et al., 2002) melaporkan bahwa kombinasi Xylanase, Amylase dan Protease terus meningkatkan lemak perut, dan direkomendasikan agar burung yang diberi makanan yang mengandung enzim mendapatkan lebih banyak energi bersih dari makanannya.

\section{KESIMPULAN}

Berdasarkan hasil penelitian ini disimpulkan : penambahan enzim (Amylase, Protease, Xylanase) Dalam pakan Efektif terhadap Penambahan berat telur dan diameter kuning telur pada itik campuran.

\section{REFERENSI}

Akhdiya, A. 2003. Isolasi Bakteri Penghasil Enzim Protease Alkalin Termostabil. Buletin Plasma Nutfah 9: 98-102.

Angel, C. R., W. Saylor, W. L. Vieira, and N. Ward. (2011). Effects of amonocomponent protease on performance and protein utilization in 7-to 22-day-old broiler chickens. Poult. Sci. 90:2281-2286. Association of Official Analytical Chemists (AOAC) 2005. Official methods of analysis, 15th edition. AOAC, Arlington, VA..

Balitbang Departemen Pertanian. 2010. Prospek dan arah pengembangan Unggas. Departemen Pertanian. 
Jakarta.

Bedford, M. R., A. J. Morgan, K. Clarkson, and H. K. Schultze,(1997). Enzyme feed additive and animal feed. US Patent 5612055.

Candrawati, D., Witariadi, N., Bidura, I., \& Dewantari, M. (2012). Pengaruh Suplementasi Enzim Phylazim dalam Ransum yang Menggunakan 30\% Dedak Padi terhadap Penampilan Broiler. Jurnal Unud, 1-11.

Chesson, A. (2001). Non-starch polysaccharide degrading enzymes in poultry diets: Influence of ingredients on the selection of activities. World Poult. Sci. J. 57:251-263.

Choct, M. (2006). Enzymes for the feed industry: past, present and future.World's Poult. Sci. J. 62:516.

Coombs, J. 1995. Dictionary of Biotechnology. Elsevier, New York.

Cowieson, A. J. (2005).Factors that affect the nutritional value of maize for broilers Anim. Feed Sci. Technol. 119:293-305.

Cowieson, A. J. (2010). Strategic selection of exogenous enzymes for corn/soy-based poultry diets. Jpn. Poult. Sci. 47:1-7.

Cowieson, A. J., and M. R. Bedford. (2009). The effect of phytase and carbohydrase on ileal amino acid digestibility in monogastric diets: Complimentary mode of action? World Poult. Sci. J. 65:609-624.

Cuche, G., J. C. Cuber, and H. Malbert. (2000). Ileal short-chain fatty acids inhibit gastric motility by a humoral pathway. Am. J. Physiol. Gastro. Liver Physiol. 279:G925G930..

DITJENAK 2008, Laporan Tahunan. Diakses tanggal 13 Desember 2020

Fernandez, F., R. Sharma, M. Hilton, and M. R. Bedford. (2000). Diet influences the colonization of Campylobacter jejuni and distribution of mucin carbohydrates in the chick intestinal tract. Cell.Mol. Life Sci. 57:1793-1801.

Forbes, J. M. 1986. The Voluntary Food Intake of Farm Animals. Butterworth \& Co., London

Garnida, D. (2012). Agriflo Itik Potensi Bisnis dan Kisah Sukses Praktis.

Ghazi, S., J. A. Rooke, and H. Galbraith. 2003. Improvement of the nutritive value of soybean meal by protease and $\alpha$-galactosidase treatment in broiler cockerels and broiler chicks. Br. Poult. Sci. 44:410-418.

Gilbert, A.B. 1971. The Female Reproductive Effort. In:Physiology and Biochemistry of the Domestic Fowl. D.J. BELL and B.M. FREEMAN (Eds.). Academic Press. London, New York

Gracia, M. I., M. J. Aran'1bar, R. L'azaro, P. Medel, and G. G. Mateos. 2003. Alpha-amylase supplementation of broiler diets basedon corn. Poult. Sci. $\quad 82: 436-442$.

Gumelar, A., \& Rahmat, A. (2016). Potensi Produksi Telur Itik di Kelompok Ternak Itik Putri Mandiri Kabupaten Karawang Jawa Barat. Journal of Animal Husbandry Science, 44-51.

Gunawan, B. 1987. Penggunaan teknologi genetika kuantitatif dalam pengembangan itik petelur Indonesia. 2: Pembentukan bibit unggul itik dari hasil kawin silang antara itik Alabio, Tegal dan Khaki Campbell yang telah diseleksi. ilmu dan Peternakan.

Hanafi, N. D. (2001). Enzim sebagai Alternatif baru dalam Peningkatan Kualitas Pakan untuk Ternak. Program pascasarjana, IPB, Bogor. Vol 12(3): 5 - 9.

Jaziri, A., Sukoso, \& Firdaus, M. (2017). Karakteristik Protease dari Ekstrak Kasar Khamir Laut dan Aktivitasnya dalam Menghidrolisis Protein Ikan Rucah. Journal of Fisheries and Marine Science, 78-87. 
Jiang, Z., Y. Zhou, F. Lu, Z. Han, and T. Wang. (2008). Effects of different levels of supplementary alphaamylase on digestive enzyme activities and pancreatic amylase mRNA expression ofyoung broilers. Asian-Austral. J. Anim. Sci. 21:97-102.

Kaczmarek, S. A., A. Rogiewicz, M. Mogielnicka, A. Rutkowski, R. O. Jones, and B. A. Slominski. (2014). The effect of protease, amylase, and non starch

polysaccharide-degrading enzyme supplementation on nutrient utilization and growth performance of broiler chickens fed corn-soybean meal-based diets. Poult. Sci. 93:1745-1753.

Ketaren, P.P. dan L.H. Prasetyo. 2000. Produktivitas itik silang MA di Ciawi dan Cirebon. Prosiding Seminar Nasional Peternakan dan Veteriner. Pusat Penelitian Peternakan, Badan Penelitian dan Pengembangan Pertanian, Departemen Pertanian.

Kriswanto, \& Wulansarie, R. (2018). IbM Usaha Ternak Bebek Petelur dan Produsen Telur Asin Kecamatan Gunungpati Kota Semarang. Abdimas, 19-26.

Kusumastuti, D., Praseno, K., \& Saraswati, T. (2012). Indeks Kuning Telur dan Nilai Haugh Unit Telur Puyuh (Coturnix Japonica L.) Setelah Pemberian Tepung Kunyit (Curcuma Longa L.). Jurnal Biologi, 15-22.

Kwakkel, R.P., Vanesch J.A.W., Ducro B.J. and KOOPS W.J (1995). Onset of lay related to multiphasic growth and body composition in White Leghorn provided ad libitum and restricted diets. Poult. Sci. 74: 821832.

Lucy, K. M. 2000. Structure and Postnatal Development of Magnum In Japanese Quail (Coturnix coturnix japonica). Mannuthy:680 651.
Mahagna, M., I. Nir, M. Larbier, and Y. Nitsan. 1995. Effect of age and exogenous amylase and protease on development of the digestive tract, pancreatic enzyme activities and digestibility of nutrients in young meat type chicks. Reprod. Nutr. Dev. 35:201-212

Mamarimbing, D., Kalangi, J., Sondakh, B., \& Lainawa, J. (2017). Analisis Manajemen Pemeliharaan Ternak Itik Petelur di Kecamatan Kakas Barat Kabupaten Minahasa. Jurnal Zootek, 216-223.

Masey O'Neill, H. V. M., S. Haldar, and M. R. Bedford. 2012. The role of peptide $Y Y$ in the mode of action of dietary xylanase. Poult. Sci. 91:217.

MacDonald, P., R.A. Edwards, J.F.D. Greenhalgh, and C.A. Morgan. 1995. Animal

Nutrition. Jhon Wiley and Sons, New York.

Musadiq, A., Nurliana, Sugito, Helmi, T., Roslizawaty, \& Razali. (2017). Efek Penyimpanan Pada Suhu Kamar dan Rfrigerator terhadap Kualitas Telur Ayam Setelah Pemberian Sinbiotik Akbisprop dalam Ransum. JIMVET, 343-350

Nangin, D., dan Sutrisno, A. 2015. Enzim Amilase Pemecah Pati Mentah dari. Mikroba: Kajian Pustaka. Jurnal Pangan dan Agroindustri 3 (3): 1032-. 1039.

Naveed, A., T. Acamovic, and M. R. Bedford. 1998. Effect of enzyme supplementation of UK-known Lupinus albus on growth performance in broiler chickens. $\mathrm{Br}$. Poult. Sci. 39:S36-S37.

Olukosi, O. A., L. A. Beeson, K. Englyst, and L. F. Romero. 2015. Effects of exogenous proteases without or with carbohydrases on nutrient digestibility and disappearance of non-starch polysaccharides in broiler chickens. Poult. Sci. 94:2662-2669. 
Park, J. H., O. K. Won, S. H. Ahn, S. Lee, B. K. Choi, and K. Y. Jung. 2013. Fatty diets retarded the propulsive function of and attenuated motility in the gastrointestinal tract of rats. Nutr.Res. 33:228-234.

Renema, R.A., Robinson F.E. Robinson, J.A. Proudman, M. Newcombe and Mckay R.I.(1999). Effect of body weight and feed allocation during sexual maturation in broiler breeder hens. 2. Ovarian morphology and plasma hormon profiles. Poult. Sci. 78: 629-639

Richana, N. (2002). Produksi dan Prospek Enzim xilanase dalam pengembangan bioindustri di indonesia. Buletin AgroBio, 5(1), 29-36.

Risnoyatiningsih, S. (2011). Hydrolysis of Starch Saccharides from Sweet Potatoes Using Enzyme. Jurnal Teknik Kimia, 417-424.

Satrio, Y., Santoso, S., \& Setiadi, A. (2015). Analisis Pengembangan Usaha Ternak Itik di Kecamatan Banyubiri Kabupaten Semarang. Animal Agriculture Journal, 256259.

Scott, M. L., M. C. Nesheim and R. J. Young. 1982. Nutrition of the Chicken. 3th Ed. M. L. Scott and Associates. Ithaca, New York.

Singh, A., H. V. M. O’Neill, T. K. Ghosh, M. R. Bedford, and S. Haldar. 2012. Effects of xylanase supplementation on performance, total volatile fatty acids and selected bacterial population in caeca, metabolic indices and peptide YY concentrations in serum of broiler chickens fed energy restricted maize-soybean based diets. Anim. Feed Sci. Technol. 177:194-203.

Sharma, R., F. Fernandez, M. Hilton, and U. Schumacher. 1997. The influence of diet on the mucin carbohydrates in the chicken tract.
Cell. Mol. Life Sci. 53:935-942. Sunarno dan Djaelani, A.M. 2011. Analisis Produktivitas Itik Petelur di Kabupaten Semarang Berdasarkan Indikator Nilai Konversi Pakan, Rasio Tingkat Konsumsi Pakan dengan Intestinum dan Bobot Intestinum dengan Pertambahan Bobot Badan. J. Sains dan Matematika. Vol. 19 (2): 38-42.

Soeparno, R.A., Rihastuti, I., dan S. Triatmojo. 2011. Dasar Teknologi Hasil Ternak. Gadjah Mada University Press, Yogyakarta.

Yuwanta, T. 2004. Dasar Ternak Unggas. Kanisius. Yogyakarta. hal. 115- 120

Zanella, I., N. K. Sakomura, F. G. Silversides, A. Figueiredo, and M. Pack. 1999. Effect of enzyme supplementation of broiler diets based on corn and soybeans. Poult. Sci. 78:561-568. 